This is an electronic reprint of the original article. This reprint may differ from the original in pagination and typographic detail.

Author(s): Lähdesmäki, Tuuli; Saresma, Tuija

Title: $\quad$ The Intersections of Sexuality and Religion in the Anti-Interculturalist Rhetoric in Finnish Internet Discussion on Muslim Homosexuals in Amsterdam

Year: $\quad 2014$

Version:

Please cite the original version:

Lähdesmäki, T., \& Saresma, T. (2014). The Intersections of Sexuality and Religion in the Anti-Interculturalist Rhetoric in Finnish Internet Discussion on Muslim

Homosexuals in Amsterdam. In J. Gourlay, \& G. Strohschen (Eds.), Building Barriers and Bridges: Interculturalism in the 21st Century (pp. 35-48). Inter-Disciplinary Press. https://doi.org/10.1163/9781848883253_005

All material supplied via JYX is protected by copyright and other intellectual property rights, and duplication or sale of all or part of any of the repository collections is not permitted, except that material may be duplicated by you for your research use or educational purposes in electronic or print form. You must obtain permission for any other use. Electronic or print copies may not be offered, whether for sale or otherwise to anyone who is not an authorised user. 


\title{
The Intersections of Sexuality and Religion in the Anti- Interculturalist Rhetoric in Finnish Internet Discussion on Muslim Homosexuals in Amsterdam
}

\author{
Tuuli Lähdesmäki and Tuija Saresma
}

\begin{abstract}
In recent decades, Europe has faced the rise of nationalist populist movements objecting to increased immigration, cultural pluralisation, and interculturalism in European societies. Public discussion on interculturalism have often focused on the encounters of - and the wrangles with - migrants and local people and their diverse values. The members of anti-immigrant movements commonly object to cultural pluralism and intercultural practices and foster 'traditional', 'Western', and 'national' values. The discourse influenced by conservative ideologies also often embraces traces of xenophobia, homophobia, and misogyny. In this paper, we ask how and why interculturalism is opposed in populist discourses. Focusing on identity formations we ask how the groups of 'us' and 'others' are produced, and analyse the rhetorical means used in demonizing others. Intersectionality as the critical recognition of hierarchically organized and constantly negotiated identity categories, such as gender, ethnicity, sexuality, social class, and religion, is our key methodological concept in analysing the complexity of the meaning-making processes in populist discourses. As our case, we analyse an article on Muslim homosexuals in Amsterdam, published in the widely read Finnish newspaper Helsingin Sanomat (3 March 2013), and the vivid discussion that followed in the online discussion forum of the newspaper. The paper demonstrates that notions of gender and sexuality are topics which can be flexibly utilized in populist discourses. On the one hand, the populist discourses are often profoundly heteronormative, fostering the idea of nuclear family, traditional gender roles, and hierarchical gender binarity. On the other hand, they may explicitly support gender equality and gay rights when the values promoted in the discourse are facing 'a bigger threat': immigration and Islam. In this case, the populist discourse can even aim to rhetorically normalize homosexuality and gender equality as an indication of developed Western rights and civilized values.
\end{abstract}

Key Words: discourse analysis, gender, ethnicity, homosexuality, immigration, interculturalism, intersectionality, Islam, populism, religion, rhetoric.

\section{Introduction: the polarization of public discussion on immigration}

In recent decades, Finland, among other European societies, has faced the rise of nationalist populist movements and political parties objecting to the increased immigration, cultural pluralisation, and loosening of so-called traditional values. In 
Finland, the rise of a populist climate is related to the success of Perussuomalaiset (The Finns Party), established in 1995. ${ }^{1}$ The party has increased its popularity in each parliamentary election, gaining a major victory in 2011 by receiving $19.05 \%$ of the vote. Despite the moderate immigration figures and relatively homogenous and monocultural Finnish society ${ }^{2}$, nationalist, 'immigration critical', or antiimmigration minded views have gained ground and prominence in public and political debates during the past decade.

Populism in general has a deeply ambivalent nature. Several scholars have emphasized that it lacks a solid core or a common ideology. ${ }^{3}$ Instead of a specific ideology, scholars have considered rhetoric as the cornerstone of populism: rhetoric constructs and mobilizes the populist movements and is thus performative and functional. ${ }^{4}$ Populist rhetoric is often described as relying on affective, emotive, and metaphoric language; polarization; simplification; stereotypification; vague expressions; and perceiving threats, faults, and enemies.

Immigration and multiculturalization are common topics in populist public and political discussions. These discussions often focus on the threats considered as outcomes of the multiculturalization of societies and the conflicts between immigrants and local people and their cultures. In populist claims, the objection to immigration and multiculturalization is commonly intertwined with the eagerness to protect and foster traditional, national, and 'Western' values. Some of the populist claims embrace xenophobia, homophobia, and misogyny. These discriminatory views are however hidden in traditionalist and nationalist discourses and the rhetoric of 'immigration criticism', in which seemingly neutral expressions are favoured. This rhetorical mechanism enables discussing 'others' using a vocabulary that veils the prejudiced or racist connotations.

In addition to public discussions, multiculturalism has been the topic of many recent critical academic investigations. It has been criticized e.g., for emphasizing boundaries instead of their blurring, and for focusing mainly on ethnic and national issues instead of paying attention to the multisectional diversity within societies. Critics have preferred to discuss the contemporary diversity and its governance using the term 'interculturalism'. Due to the discursive nature of politics, political innovations are always conceptual and conceptual changes embody politics. ${ }^{6}$ The concept of interculturalism signifies both a political innovation and a conceptual change in diversity policies. It emphasizes dialogue as a means for understanding and respecting the difference. Dialogue is by definition not just a negotiation between differing opinions: its aim is 'to achieve a new understanding as a foundation for thinking and action'? Dialogue does not, however, presume harmonious agreement. In dialogue, the difference of opinion may be a key factor in opening up new points of view. Difference and dialogue are operationalized in the policies and discourses of interculturalism as a means for a tolerant multicultural society. Departing from this ideal of interculturalism, the public 'dialogue' on the encountering of cultures, values, and people does not always 
broaden the understanding of difference. Particularly the anonymous online discussions on intercultural policies and practices have, on the contrary, reinforced black-and-white argumentation, stereotypification, discriminating expressions, and aggressive rhetoric. ${ }^{8}$

The ideal of a dialogue in intercultural encounters is the starting point of this paper. What is the outcome of an online 'dialogue' on intercultural conflicts? How are the groups of 'us' and 'others' produced in the dialogue, and to what aims? How is the dialogue on intercultural encounters intertwined with notions of gender, sexuality, and religion? Intersectionality as a critical recognition of hierarchically organized and constantly negotiated identity positions is our key theoretical concept. The investigation focuses on a restricted case study: an article on Muslim homosexuals in Amsterdam published in a Finnish newspaper Helsingin Sanomat, and the vivid discussion that followed on the discussion forum of the newspaper. The analysis demonstrates how identity positions, such as sexuality and religion, intersect in public discussions.

\section{Intersectionality as a critical method of analyzing populist discourses}

Intersectional categories of gender, race, and social class first became the focus of research in black feminist thought. ${ }^{9}$ In feminist theory, it has become almost impossible to talk about gender without discussing its connections with sexuality, class, and ethnicity. ${ }^{10}$ The concept of intersectionality emphasizes the situation of individuals in changing hierarchical positions of power: the male is often comprehended as higher in the hierarchy than the female; however a black male might be lower than a white female; and the setting becomes even more complicated when more differences, such as social class, sexuality, or religion, are taken into account.

Although intersectionality has been discussed extensively in feminist theory, the empirical implications of the concept demonstrate the challenges of deciding which categories are relevant at the given time. While ethnicity and race, especially whiteness, have been analyzed in relation to populist discourses ${ }^{11}$, gender and populism remain under-researched areas ${ }^{12}$. Like gender, issues of sexuality have not yet been the focus of studies on populist discourses. ${ }^{13}$

Intersectionality as the critical recognition of hierarchically organized and constantly negotiated identity positions is the key methodological concept in our analysis of the complexity of the meaning-making processes in populist discourses. Our aim is to analyze how the categories of gender, sexuality, and religion function together and produce each other performatively. ${ }^{14}$ Some of the categories are defined as cultural and others as 'inborn', but despite their differences, they function simultaneously as essential building blocks of individual identities and experiences of belonging in the society. The challenge for the research is to take into account all the relevant positions and the performative power of the researcher in categorizing, analyzing, and contextualizing the findings. We aim to answer 
these challenges by investigating how the intersecting hierarchical positions of power are constructed in the populist anti-immigration discussion.

\section{Analysis of print and online texts on Muslim Homosexuals in Amsterdam}

Despite the extensive interest among scholars in the development and emergence of radical right-wing populist parties, surprisingly little attention has been given to the role of non-party groups in facilitating populism as a broader phenomenon. ${ }^{15}$ In this paper, we have chosen to focus on civic activity outside party politics. Blogs and online discussion fora are central sites for contemporary civic debate $^{16}$, although traditional print media and television are still influential in shaping public opinion. Our analysis focuses on the combination of these two media: a newspaper article and an online discussion on the topic.

What follows is a summary of the article, discussed from an intersectional point of view. The article 'The downside of liberalism in the Netherlands' by the journalist Kaisa Viitanen was published in the Sunday supplement of the leading newspaper in Finland, Helsingin Sanomat in March 3, 2013. ${ }^{17}$ In the headline and the introductory chapter, the flip side of the liberalist Netherlands is portrayed with strong expressions: In this liberal gay paradise, 'the gender-neutral marriage was legalized a long time ago, and now even Muslim gay men dare to come out of the closet'. However, 'lately gays have been beaten on the streets of Amsterdam. They are threatened by young men with Moroccan background claiming that by doing this they obey the instructions of the Quran.'

In the rhetoric of the article, the threat to the tolerant Western democratic country comes from outside. Echoes of romantic Orientalism are heard when sketching the setting of the article in a lively manner:

Shining sweat and swinging pelvises. The famous Amsterdam concert hall, located in a former church, has changed into an oriental party Mecca, the Paradiso. DJ's are tooting Turkish music in three halls. Devout dervishes spin at the main stage until their gowns suddenly unwind exposing tanned dancer bodies.

The dark haired male audience bursts with enthusiasm, some whistle in the manner of Arab women, waving their palm in front of their mouth. ${ }^{18}$

With these exotic images, the dichotomy between 'us' and 'them' - the undertone throughout the story - is created. The demarcation line is constructed between the liberal 'us' and the intolerant Muslim 'them' by emphasizing the liberal atmosphere of the 'gay capital of Europe' with its Pride parades and active party scene, and the change that took place with the increasing immigration of Muslims. Now - as the article has it - the members of the sexual minorities feel 
threatened, the statistics show increased harassment, and tourists belonging to sexual minorities are warned not to walk hand in hand.

In the article, the perpetrators behind the increasing violence and threat are '[y]oung men between 17 and 24 years, born in the Netherlands but with Moroccan background'. It is claimed that harassment has led to a change in national politics: the members of sexual minorities have moved from the left to the right and 'the far right leader' Geert Wilders has claimed that he wants to make the Netherlands the 'safe haven for gay people'.

The writer of the article places the Muslim gay people living between two cultures in a difficult situation where they fall between the polarized value positions of the liberal West and the Quran-led fundamentalism. According to the interviews by the journalist, most of the Muslim gays in Amsterdam do not feel threatened: 'It seems that street violence is not as big a problem for the Muslim gay people as it is to the white Dutchmen'. The reason for this is simple: 'most Muslim gays still live in the closet'. According to the article, a change is, however, about to happen. 'The Muslim population of the Netherlands is debating about its opinions on sexual minorities and women's rights.' The story about the change of attitudes ends with a return to the gay disco, where 'the Muslim, Jewish, Hindi, Christian, and atheist people surrender to the swinging Turkish rhythm the DJ toots'.

Ninety-one comments were posted as a response to the article on the web site of Helsingin Sanomat. The intersectional rhetoric of the comments was investigated with qualitative content analysis. The themes of homosexuality and religion permeated practically all of the comments. They were never discussed explicitly in relation to e.g., heterosexuality, but the writers of both the article and most of the comments positioned themselves as straight and the homosexuals as their others. ${ }^{19}$ Similarly to the conjectural heterosexuality of the debaters, the male gender was presupposed for both the debaters and the homosexuals in Amsterdam. Religion as a theme permeated the discussion dealing with Muslim gays. It was however tackled in a more subtle way than homosexuality, bringing forth the differences in religious attitudes and the questions of secularization and loss of traditional values.

In the content analysis, the comments ${ }^{20}$ were divided into six thematic categories: 1) party politics, 2) tolerance, 3) aggression, 4) defending or attacking certain named individuals, 5) culture/civilization, and 6) gender. Most comments fell into the three first mentioned categories and they will be analyzed next in relation to the intersections of homosexuality and religion. ${ }^{21}$

\section{A. Finnish party politics}

Even though the article discussed the situation of Muslim homosexuals in the Netherlands, the most common topic in the online discussion focused on Finnish party politics. All parties in the Finnish Parliament and their attitudes towards immigrants and homosexuals were drawn to the discussion. However, the discussion polarized between the debaters supporting The Finns Party and those 
objecting to it (often positioned as urban leftist-green by the supporters of the former). In the debate, homosexuals were turned into a political pawn: many of the debaters considered that homosexuals in Finland have to be protected from the intolerant immigrants, while others claimed that homosexuals in Finland were discriminated by the supporters of nationalist and populist movements.

Many of the debaters supporting The Finns Party interpreted the topic of the article as an indication of the faults caused by the immigration from Islamic countries to the Christian and liberal West. In these views, immigrants were narrowly discussed as a unified group (of Muslims) promoting fundamentalist values which collide with the Western notions on democracy, gender equality, and liberal individual rights. Many of the debaters encouraged The Finns Party to explicitly take on their agenda the protection of Finnish homosexuals against 'the immigration of people coming from homophobic cultures', as the person posting as "Keeko" stated. ${ }^{22}$ In these views, Finnish (Christian) homosexuals were ranked higher in the societal hierarchy than (heterosexual, male) Muslim immigrants. The ideology of protecting Western values and monocultural societies in Europe was manifested in the debate in the defence of homosexuals. At the same time, homosexuals and women were accused of supporting immigration and multiculturalization. Many of the debaters blamed them for being too liberal and supporting political parties which promote the (fundamentalist, Muslim) immigration that produces a threat for both homosexuals and women. These views described (male) homosexuals and women as liberalist, politically leftist-green underdogs, as opposed to the nationalist, conservative heterosexual men objecting to immigration and justly worried about the order of the society.

B. (Not) tolerating the tolerant

In the populist anti-immigrant discourse, 'the Tolerant' as a word and a group of people refers to the 'reddish-green women' with liberal-leftist values who are considered by anti-immigration minded people to be naively pro-immigration. In the data, 'the Tolerant' were considered also to support the gay rights 'without critique' unlike the 'moderate liberals' who object to e.g., the gender-neutral marriage and gay couples' right to adoption (following The Finns Party leader Timo Soini, who participated in a demonstration against gender-neutral marriage in France in 2013) but who 'does not hate gays'. ${ }^{23}$

The basic question for the debaters in the data was whether to 'tolerate the Tolerant', as the "The Guy from the Right” writes. The supposed naïve liberalism of 'the Tolerant' is juxtaposed with 'real tolerance'. With this oxymoron, the debaters referred to restricting the immigration of Muslims in order to promote the gay rights of Western people. Gays in the West are endangered, according to these debaters, because Muslims 'trample over the real tolerance', as the "The Beast Girl" has it. Many comments claimed that Europe is the final frontier of liberal values and this 'atmosphere of tolerance' should be defended. Thus, in these 
comments the 'real tolerance' referred to 'Western' liberal attitudes toward homosexuals - but only when it promoted the restriction of immigration. In the data, 'tolerance' was only a buzzword with an empty meaning.

\section{Affective aggression}

In addition to the analytical party speech and rationally argued tolerance speech, the comments also included an affective discourse of aggression and threat. The discourse of aggression was emotionally construed as a counter-attack to liberal values. The comments embraced discussions on persecution on the basis of religion, of sending people to prison, of death sentences, and of burning people alive. Some debaters predicted that the long era of peace in Europe will soon be history, as the Shia and Sunni Muslims bring their battle to the continent. It was claimed that a wave of violence has hit Europe in the form of religious intolerance which has already burst as fulmination and violence against gay people. This comment from “AnimalFarm” illustrates the repeated argument:

We have so few [Muslims] in Finland that they haven't dared to start campaigning according to their violent dogmatics yet. Let's hope the amount will be held in check so that we'll manage to avoid their aggression familiar elsewhere in Europe. Malmö, Berlin, Paris... ${ }^{24}$

Alternatively, some of the debaters in the data considered the Finnish nationalist right-wing activists to be a bigger threat to gays, liberal values, and European civilization than the extreme Islamists. ${ }^{25}$ In both cases, instead to trying to stop the aggressive behaviour, it was constructed as an evident result of immigration.

\section{Discussion and conclusions}

The concept of intersectionality embraces the idea of intersections of diverse identity categories and their mutual co-production much like the idea of interaction of cultures is emphasized in the concept of interculturalism. As the paper indicates, intercultural encounters (or conflicts) include intersectional complexity: discussions on immigration reveal how the notions on religion, culture, political commitments, moral values, justice, gender, and sexuality are intertwined and produce hierarchical power structures between people. In the power hierarchy, some positions are uplifted, while some others are treated as subordinated. Discrimination based on sexual orientation and religion was explicit in the data. One of the commonly used discriminating rhetorical strategies was the essentialization of groups of people and their identity categories. Especially Muslims and Islam were often determined as an essentialist, unchanging, and monocultural entity. Even though the focus of the newspaper article was on Muslim homosexuals and their liberal life style in Amsterdam, the Finnish debaters 
did not discuss the inner diversity of Muslims and the adaptability of Islam, particularly as it relates to modernity, liberalism, and democracy in European societies. $^{26}$

As the paper demonstrates, notions of gender and sexuality are topics which can be flexibility utilized in populist discourses. On the one hand, the populist discourses are often profoundly heteronormative in fostering the idea of nuclear family, traditional gender roles, and hierarchical gender binarity ${ }^{27}$. Thus, the populist discourses may include both implicit and explicit homophobic and chauvinist attitudes and the 'othering' of homosexuals and women. On the other hand, they may explicitly support gender equality and gay rights when the values promoted in the discourse are facing 'a bigger threat': immigration and Islam. In this case, the populist discourse can even aim to rhetorically normalize homosexuality and gender equality as an indication of developed Western rights and civilized values.

The online discussions enable a public dialogue about intercultural encounters. In the case of the paper, the dialogue lacked immigrant or Muslim participants. In the debate, the views on religion and sexuality polarized: instead of broadening the understanding on the complexity of the topic, the views narrowed to profoundly black-and-white notions of groups of people, identity categories, and their interaction. The idea and ideal of an intercultural dialogue seem not to work in online debates: instead of mutual and interactive dialogue, they rather strengthen the juxtaposition and polarization of opinions.

\section{Notes}

1 The name of the party was retranslated as 'The Finns Party' after the Parliamentary election in 2011. Previously, the party used the translation 'The True Finns'.

2 In 2012, 3.6\% of the population in Finland were foreigners with the Estonians, Russians, and Swedes as biggest nationality groups. $1.4 \%$ of the population were registered to a religious community other than the Lutheran or Eastern Orthodox Church. 31278 people immigrated to the country. Statistics Finland, 'Population', updated Jan 17, 2014, http://www.stat.fi/tup/suoluk/suoluk_vaesto_en.html.

3 E.g., Gianfranco Pasquino, 'Populism and Democracy,' Twenty-First Century Populism. The Spectre of Western European Democracy, eds. Daniele Albertazzi and Duncan McDonnell (Hampshire: Palgrave MacMillan, 2008), 15-29; Ernesto Laclau, On Populist Reason (London: Verso, 2005).

${ }^{4}$ Laclau, On Populist Reason.

5 Katariina Mäkinen, 'Rajoja ja säröjä. Talous maahanmuuttovastaisessa keskustelussa,’ Poliittinen talous 1.1 (2013),

http://www.poliittinentalous.fi/ojs/index.php/poltal/article/view/2. 
${ }^{6}$ James Farr, 'Understanding Conceptual Change Politically,' Political Innovation and Conceptual Change, eds. Terence Ball, James Farr and Russell L. Hanson (Cambridge: Cambridge University Press, 1989), 31.

${ }^{7}$ William Isaacs, Dialogi ja yhdessä ajattelemisen taito (Helsinki: Kauppakaari, 2001), 40.

${ }^{8}$ Sanna Karkulehto, Tuija Saresma, Hannele Harjunen and Johanna Kantola, 'Intersektionaalisuus metodologiana ja performatiivisen intersektionaalisuuden haaste,' Naistutkimus-Kvinnoforskning 25. 4 (2012): 17-28.

${ }^{9}$ Kimberlé Crenshaw, 'Mapping the Margins: Intersectionality, Identity Politics, and Violence against Women of Color,' Stanford Law Review 43.6 (1991): 12411299.

10 Kathy Davis, 'Intersectionality as Buzzword. A Sociology of Science Perspective on What Makes a Feminist Theory Succesful,' Feminist Theory 9.1 (2008): 67-85.

11 Suvi Keskinen, 'Antifeminism and White Identity Politics. Political Antagonisms in Radical Right-Wing Populist and Anti-Immigration Rhetoric in Finland,' Nordic Journal of Migration Research 3.4 (2013): 225-232; Thomas Hübinette and Catrin Lundström, 'Sweden after the Recent Election: the Doublebinding Power of Swedish Whiteness through the Mourning of the Loss of "Old Sweden" and the Passing of "Good Sweden",' NORA-Nordic Journal of Feminist and Gender Research 19.1 (2011): 42-52.

${ }^{12}$ Ov Cristian Norocel, Our People - A Tight-Knit Family under the Same Protective Roof. A Critical Study of Gendered Conceptual Metaphors at Work in Radical Right Populism (Helsinki: University of Helsinki, 2013), 34; Diana Mulinari and Anders Neergard, 'Violence, Racism, and the Political Arena: A Scandinavian Dilemma,' NORA-Nordic Journal of Feminist and Gender Research 20.1 (2012): 12-18.

${ }^{13}$ With exceptions like e.g., Tuija Saresma, 'Miesten tasa-arvo ja kaunapuhe blogikeskustelussa,' Sukupuoli nyt! Purkamisia ja neuvotteluja, eds. Hannele Harjunen and Tuija Saresma (Jyväskylä: Kampus Kustannus, 2012), 13-34; Norocel, Our People - A Tight-Knit Family under the Same Protective Roof.

${ }^{14}$ Sanna Karkulehto, Tuija Saresma, Hannele Harjunen and Johanna Kantola, Johanna, 'Intersektionaalisuus metodologiana ja performatiivisen intersektionaalisuuden haaste'.

${ }^{15}$ Juris Pupcenoks and Ruan McCabe, 'The Rise of the Fringe: Right Wing Populists, Islamists and Politics in the UK.,' Journal of Muslim Minority Affairs 33.2 (2013): 171.

16 Hallvard Moe, 'Mapping the Norwegian Blogosphere: Methodological Challenges in Internationalizing Internet Research,' SAGE Internet Research Methods, ed. Jason Hughes (London: Sage, 2011), IV125-IV143; Jaakko 
Suominen, Sari Östman and Petri Saakikoski, Sosiaalisen median lyhyt historia (Helsinki: Gaudeamus, 2013).

${ }^{17}$ The main article in Helsingin Sanomat included two other articles on the same topic: 'Isjed Hussain: “God made me gay”', by Kaisa Viitanen, and 'Seta - LGBTI Rights in Finland: The juxtaposition of gays and Muslims is not shown in Finland' by Juha Peurala. In addition, the online version of the newspaper included an article 'Döne Fil: "I am lesbian, but I can still pray"', by Kaisa Viitanen. The articles in Helsingin Sanomat also produced discussion on several other Finnish online discussion fora and blogs.

${ }^{18}$ Viitanen 2013.

${ }^{19}$ There was one exception to this 'presumption of heterosexuality': one of the debaters explicitly declared being gay and demonstrated his knowledge on European gay culture and history.

${ }^{20}$ The comments were usually between one to ten sentences long and were mostly categorized as a whole; in some cases, if the posted comment included several sections, they were divided into two or more categories.

${ }^{21}$ The fourth category (embracing manifold intertextual references) consisted of tens of comments defending the Member of the Finnish Parliament Jussi Halla-aho, who was mentioned in the newspaper article, and a couple of comments attacking the journalist Umayya Abu-Hanna, who had declared Finland to be a racist country before moving to Amsterdam only a couple of months before the journal article was published. The fifth category comprised of only 5 comments and the sixth category only of 4 comments. We will not analyse the last three categories here due to lack of space. However, gender in general will be discussed as an important intersection in the conclusions of the paper.

${ }^{22}$ Quotations in the paper are from the comments written in March 3, 2013 on the online discussion section of the article 'Hollannin vapaamielisyydellä on varjopuoli' by Kaisa Viitanen, published in Helsingin Sanomat, Mar 3, 2013, http://www.hs.fi/sunnuntai/a1362200088627.

${ }^{23}$ Many of the people criticizing the current immigration policies in Finland are also against gender-neutral marriage and adoption rights for gay couples. E.g., the program of the Finns Party in the previous parliamentary election in 2011 included a clear comment on gender-neutral marriage and gay couples' rights for adoption: the party does not accept them.

24 AnimalFarm 2013. A comment published March 3, 2013 on the online discussion of the article 'Hollannin vapaamielisyydellä on varjopuoli' in Helsingin Sanomat, viewed 11.4.2014, //www.hs.fi/sunnuntai/a1362200088627.

${ }^{25}$ The frequency of Finnish domestic violence - drunken husbands beating their wives - was brought out by the debaters who considered the Finnish nationalist right-wing activists as a bigger threat to Finnish society than Islamists. The 
debaters objecting Muslim immigration replied by noting that the Finnish wifebeaters do not use the Bible, like the Muslims use the Quran, as a justification for violence.

${ }^{26}$ See discussion on the diversity and adaptation of Islam e.g., Ahmet Yukleyen, 'Localizing Islam in Europe: Religious Activism among Turkish Islamic Organizations in the Netherlands,' Journal of Muslim Minority Affairs 29.3 (2009): 291-309.

${ }^{27}$ Norocel, Our People - A Tight-Knit Family under the Same Protective Roof, 21.

\section{Bibliography}

AnimalFarm 2013. A comment published March 3, 2013 on the online discussion of the article 'Hollannin vapaamielisyydellä on varjopuoli' in Helsingin Sanomat. Viewed 11.4.2014, //www.hs.fi/sunnuntai/a1362200088627.

Crenshaw, Kimberlé. 'Mapping the Margins: Intersectionality, Identity Politics, and Violence against Women of Color.' Stanford Law Review 43.6(1991): 12411299.

Davis, Kathy. 'Intersectionality as Buzzword. A Sociology of Science Perspective on What Makes a Feminist Theory Succesful.' Feminist Theory 9.1(2008): 67-85.

Farr, James. 'Understanding Conceptual Change Politically.' Political Innovation and Conceptual Change, edited by Terence Ball, James Farr and Russell L. Hanson, 24-49. Cambridge: Cambridge University Press, 1989.

Hübinette, Thomas and Catrin Lundström. 'Sweden after the Recent Election: the Double-binding Power of Swedish Whiteness through the Mourning of the Loss of "Old Sweden" and the Passing of "Good Sweden".' NORA-Nordic Journal of Feminist and Gender Research 19.1(2011): 42-52.

Isaacs, William. Dialogi ja yhdessä ajattelemisen taito. Helsinki: Kauppakaari, 2001.

Karkulehto, Sanna, Tuija Saresma, Hannele Harjunen and Johanna Kantola. 'Intersektionaalisuus metodologiana ja performatiivisen intersektionaalisuuden haaste.' Naistutkimus-Kvinnoforskning 25. 4(2012): 17-28.

Keskinen, Suvi. 'Antifeminism and White Identity Politics. Political Antagonisms in Radical Right-Wing Populist and Anti-Immigration Rhetoric in Finland.' Nordic Journal of Migration Research 3.4(2013): 225-232. 
Laclau, Ernesto. On Populist Reason. London: Verso, 2005.

Mäkinen, Katariina. 'Rajoja ja säröjä. Talous maahanmuuttovastaisessa keskustelussa,' Poliittinen talous 1.1(2013). Viewed 17 Feb 2014.

http://www.poliittinentalous.fi/ojs/index.php/poltal/article/view/2.

Moe, Hallvard. 'Mapping the Norwegian Blogosphere: Methodological Challenges in Internationalizing Internet Research.' SAGE Internet Research Methods, edited by Jason Hughes, IV125-IV143. London: Sage, 2011.

Mulinari, Diana and Anders Neergard. 'Violence, Racism, and the Political Arena: A Scandinavian Dilemma.' NORA-Nordic Journal of Feminist and Gender Research 20.1(2012): 12-18.

Norocel, Ov Christian. Our People - a Tight-knit Family under the Same Protective Roof. A Critical Study of Gendered Conceptual Metaphors at Work in Radical Right Populism. Helsinki: University of Helsinki, 2013.

Pasquino, Gianfranco. 'Populism and Democracy.' Twenty-First Century Populism. The Spectre of Western European Democracy, edited by Daniele Albertazzi and Duncan McDonnell, 15-29. Hampshire: Palgrave MacMillan, 2008.

Pupcenoks, Juris and Ruan McCabe. 'The Rise of the Fringe: Right Wing Populists, Islamists and Politics in the UK..' Journal of Muslim Minority Affairs 33.2(2013): 171-184.

Saresma, Tuija. 'Miesten tasa-arvo ja kaunapuhe blogikeskustelussa.' Sukupuoli nyt! Purkamisia ja neuvotteluja, edited by Hannele Harjunen and Tuija Saresma, 13-34. Jyväskylä: Kampus Kustannus, 2012.

Statistics Finland. 'Population.' Updated Jan 17, 2014. Viewed 17 Feb 2014. http://www.stat.fi/tup/suoluk/suoluk_vaesto_en.html.

Suominen, Jaakko, Sari Östman and Petri Saakikoski. Sosiaalisen median lyhyt historia. Helsinki: Gaudeamus, 2013.

Viitanen, Kaisa. 'Hollannin vapaamielisyydellä on varjopuoli.' Helsingin Sanomat 3 Mar 2013, Sunday Supplement. Viewed 17 Feb 2014. http://www.hs.fi/sunnuntai/a1362200088627. 
Yukleyen, Ahmet. 'Localizing Islam in Europe: Religious Activism among Turkish Islamic Organizations in the Netherlands.' Journal of Muslim Minority Affairs 29.3(2009): 291-309.

Docent Tuuli Lähdesmäki, PhD, and Docent Tuija Saresma, PhD, are Senior Researchers at the Department of Art and Culture Studies in the University of Jyväskylä, Finland. This paper is part of a research project 'Populism as movement and rhetoric' funded by the Academy of Finland (SA21000019101). 